\title{
Evaluation of acceptability, safety and expulsion rate of PPIUCD
}

\section{R. Chauhan, Sonal Sahni, Shaily Hanumantaiya*}

Department of Obstetrics and Gynecology, N. S. C. B Medical College, Jabalpur, Madhya Pradesh, India

Received: 08 January 2018

Accepted: 03 February 2018

\section{*Correspondence:}

Dr. Shaily Hanumantaiya,

E-mail: shaily.hanumantaiya@gmail.com

Copyright: (C) the author(s), publisher and licensee Medip Academy. This is an open-access article distributed under the terms of the Creative Commons Attribution Non-Commercial License, which permits unrestricted non-commercial use, distribution, and reproduction in any medium, provided the original work is properly cited.

\begin{abstract}
Background: The modern intrauterine contraceptive device (IUCD) is highly effective, safe, private, long acting, coitus independent, rapidly reversible, cost effective and can be used by women who are breastfeeding. This study was conducted to evaluate factors associated with acceptability, safety and expulsion rates of PPIUCD among clients in the Department of Obstetrics and Gynecology, N. S. C. B Medical College, Jabalpur.

Methods: A questionnaire based prospective study was conducted between March 2016 -17 on all the clients who were counseled for PPIUCD and who fulfilled the WHO Medical Eligibility criteria. Proforma included follow up at 6 weeks post-delivery.

Results: In our study 961 women accepted PPIUCD (53.3\%). Majority of the cases belonged to low socioeconomic group with low literacy rates. Most acceptors counseled in antenatal period (53.1\%). Majority (67.3\%) of insertions were post placental and instrumental (89\%). At the time of insertion most clients experienced mild pain (49.7\%) \& anxiety (42.5\%). Amongst clients who followed up (51.1\%), the most common complaint was pain $(16.7 \%)$ and most common reason for removal was heavy bleeding. Continuation rate was $77.7 \%$, spontaneous expulsion in $9.75 \%$ while voluntarily removal was done in $12.6 \%$. At follow up $91.3 \%$ clients were satisfied with PPIUCD.

Conclusions: Antenatal counseling has a very important role. Demographic factors influencing acceptance are education, socioeconomic status and family structure. PPIUCD is demonstrably safe and effective method of contraception with low expulsion rate. Awareness about the safety and efficacy of PPIUCD should be emphasized during antenatal visits.
\end{abstract}

Keywords: Awareness, Contraception, Intrauterine contraceptive device, PPIUCD, Postpartum period

\section{INTRODUCTION}

India, with a population of over 1.2 billion is slated to overtake China as the world's most populous country, in less than one and a half decade. Family planning is important not only for population stabilization, but is also central to improve maternal and child health in our country.

According to a 2012 report of World Bank, UNFPA, WHO. India contributes to $20 \%$ of maternal deaths worldwide. ${ }^{2}$ Family planning can avert more than $30 \%$ of maternal deaths and $10 \%$ of child mortality if couples spaced their pregnancies at least 2 years apart. ${ }^{3}$

Over the years, India's Family Planning Programme has evolved with the shift in focus from mere population control to more critical issues like reducing maternal mortality and improving the health of mother and newborn. Ensuring healthy timing and spacing of pregnancies is now considered the most important intervention for reproductive, maternal, neonatal, child and adolescent health $(\mathrm{RMNCH}+\mathrm{A}) .{ }^{4}$ Another shift is the 
renewed emphasis on spacing methods of family planning. ${ }^{1}$

Significantly increased institutional deliveries after introduction of JSY (Janani Suraksha Yojana) in India provides an opportunity for offering family planning services to the women, who have just delivered at health centers and want to prevent unintended pregnancies or delay having more children. Moreover, the unmet need for family planning is very high in the postpartum period. Utilizing this immediate postpartum period for counseling on family planning and IUCD insertion will overcome multiple barriers to service provision.

Despite the many advantages of the IUCD as a method of family planning, it generally suffers from unpopularity in India. Use of modern contraceptive methods in the country is limited to $47.8 \%$ and that of IUCD to only 1.5 $\%$ (NFHS 2015-16). Recently, however, the MOHFW (Ministry Of Health and Family Welfare) has been trying to increase the use of spacing methods. ${ }^{5}$

\section{METHODS}

A prospective, questionnaire based observational study was conducted between $1^{\text {st }}$ March 2016 to $31^{\text {st }}$ March 2017 in the Department of Obstetrics and Gynecology, Netaji Subhash Chandra Bose Medical College and Hospital, Jabalpur (MP).

WHO Medical Eligibility criteria was followed. It has four categories. ${ }^{5}$

- No restriction for the use.

- Advantages of using method outweigh the risks.

- Risks outweigh the advantages of using method.

- Unacceptable health risk if method used.

\section{Inclusion criteria}

All antenatal patients admitted for delivery and post partum patients in our hospital were counseled for PPIUCD. Consent was obtained from those, who opted for insertion.

Those who fulfilled the following criteria were considered for inclusion

- 18-45 years old.

- Desire to have IUCD after counselling, before insertion.

- No local infections.

- $\mathrm{Hb}>10 \mathrm{gm} \%$.

\section{Exclusion criteria}

- Fever during labor and delivery.

- Having active STD (Sexually Transmitted Disease) or other lower genital tract infection or high risk for STD.
- Known to have ruptured membranes for more than $18 \mathrm{hrs}$ prior to delivery.

- Known uterine abnormalities e.g., Bicornuate/septate, uterine myomas.

\section{Post partum IUD (PPIUCD) insertion}

It is the insertion of IUD within 48 hours after delivery. It is of 3 types on the basis of insertion time. ${ }^{1}$

\section{Post placental insertion}

Insertion within 10 minutes following delivery of the placenta following a vaginal delivery.

\section{Intra cesarean insertion}

Insertion that take place during a cesarean delivery, after removal of the placenta and before closure of the uterine incision.

\section{Post partum before discharge}

Insertion of IUD within 48 hours after delivery and before the women leaves the facility where she delivered.

\section{Steps of IUCD insertion ${ }^{1}$}

An informed consent was taken and woman's records were checked to ensure that she is an appropriate client, ruling out conditions which prevent IUCD insertion. Client was explained about the procedure and queries were answered. Under all aseptic precautions IUCD was inserted with aid of PPIUCD inserting forceps using a notouch technique. Confirmation of proper PPIUCD insertion was done when the forceps reached the fundus as felt by the resistance offered and the thrust of the instrument felt per abdomen. PPIUCD insertion forceps after releasing IUCD at fundus is swept to the right along the side wall of the uterus ensuring they are away from the IUCD and removed from uterine cavity, keeping it slightly open. Particular care was taken not to dislodge the IUCD as PPIUCD insertion forceps are removed. Cervix was examined to ensure there is no trauma. Women were provided with post insertion instructions. Information regarding the PPIUCD insertion was recorded with the patient as well as in the PPIUCD register.

At discharge women were informed about the side effects, warning signs and follow up schedule and advised to report immediately in case of untoward signs. At follow up examination, patient's satisfaction was assessed and complications like bleeding, pain and infection were treated appropriately.

In case of discomfort due to long thread, cutting short of thread was done. The women in whom the procedure was uneventful were requested to follow up at 6 months. 


\section{RESULTS}

This study was conducted to evaluate PPIUCD as a family planning method and the observations were analyzed as shown below.

After post partum family counselling of 1800 clients total 961 women accepted PPIUCD as a method of contraception $(53.3 \%)$. Acceptance of PPIUCD was highest in Hindu women, women from rural areas and those belonging to joint families. The lower and middle socioeconomic class had good acceptance. The acceptance rose with the level of education of the patients and their partners. Majority of the women who accepted were homemakers and their partners were mostly laborers (Table 1).

Table 1: Distribution of cases according to sociodemographic characteristics.

\begin{tabular}{|c|c|c|c|}
\hline \multicolumn{2}{|c|}{ Characteristics } & \multirow{2}{*}{$\begin{array}{l}\text { No. of cases } \\
(n=961) \\
894\end{array}$} & \multirow{2}{*}{$\begin{array}{l}\% \\
93\end{array}$} \\
\hline \multirow{3}{*}{ Religion } & Hindu & & \\
\hline & Muslim & 53 & 5.5 \\
\hline & Others & 14 & 1.5 \\
\hline \multirow{2}{*}{ Locality } & Rural & 602 & 62.6 \\
\hline & Urban & 359 & 37.4 \\
\hline \multirow{2}{*}{$\begin{array}{l}\text { Type of } \\
\text { family }\end{array}$} & Nuclear & 410 & 42.7 \\
\hline & Joint & 551 & 57.3 \\
\hline \multirow{3}{*}{$\begin{array}{l}\text { Socio- } \\
\text { economic } \\
\text { status }\end{array}$} & Lower & 479 & 49.8 \\
\hline & Middle & 437 & 45.5 \\
\hline & Upper & 45 & 4.7 \\
\hline \multirow{4}{*}{$\begin{array}{l}\text { Education of } \\
\text { client }\end{array}$} & $\begin{array}{l}\text { No formal } \\
\text { education }\end{array}$ & 186 & 19.4 \\
\hline & Primary & 254 & 26.4 \\
\hline & High school & 476 & 49.5 \\
\hline & Graduate & 45 & 4.7 \\
\hline \multirow{4}{*}{$\begin{array}{l}\text { Education of } \\
\text { partner }\end{array}$} & $\begin{array}{l}\text { No formal } \\
\text { education }\end{array}$ & 74 & 7.7 \\
\hline & Primary & 204 & 21.2 \\
\hline & High school & 532 & 55.4 \\
\hline & Graduate & 151 & 15.7 \\
\hline \multirow{5}{*}{$\begin{array}{l}\text { Occupation } \\
\text { of client }\end{array}$} & Home maker & 751 & 78.1 \\
\hline & Farmer & 14 & 1.5 \\
\hline & Labourer & 133 & 13.8 \\
\hline & Govt Servent & 17 & 1.8 \\
\hline & Business & 46 & 4.8 \\
\hline \multirow{5}{*}{$\begin{array}{l}\text { Occupation } \\
\text { of partner }\end{array}$} & Unemployeed & 15 & 1.6 \\
\hline & Farmer & 53 & 5.5 \\
\hline & Labourer & 593 & 61.7 \\
\hline & Govt Servent & 82 & 8.5 \\
\hline & Business & 218 & 22.7 \\
\hline
\end{tabular}

As depicted in Table 2, the maximum number of cases were counseled for PPIUCD insertion antenatally, during early labor/ preparation for LSCS.

As shown in the Table 3, majority of the insertion were post placental $(67.3 \%)$.
As depicted in the Table 4, most clients had mild pain (49.7\%) and little anxiety $(42.5 \%)$ at the time of PPIUCD insertion.

Table 2: Distribution of cases according to timing of counselling.

\begin{tabular}{|lll|}
\hline $\begin{array}{l}\text { Timing of } \\
\text { counselling }\end{array}$ & No. of cases $(\mathrm{n}=961)$ & $\%$ \\
\hline ANC period & 510 & 53.10 \\
\hline $\begin{array}{l}\text { Early labor or } \\
\text { Preparation for LSCS }\end{array}$ & 349 & 36.30 \\
\hline After delivery & 94 & 9.80 \\
\hline Postpartum stay & 8 & 0.80 \\
\hline
\end{tabular}

Table 3: Distribution of cases according to type of IUCD insertion.

\begin{tabular}{|lll|}
\hline Type of insertion & No. of cases $(n=961)$ & $\%$ \\
\hline Post placental & 647 & 67.30 \\
\hline Post partum & 8 & 0.80 \\
\hline Intra caesarean & 306 & 31.80 \\
\hline Total & 961 & 100.00 \\
\hline
\end{tabular}

Out of the 961 cases who opted for IUCD insertion as a preferred contraceptive method, $492(51.1 \%)$ reported for follow up. At follow up $26.2 \%$ clients reported problems while others enrolled for routine check-up.

Table 4: Distribution of cases according to perception of symptoms on PPIUCD insertion.

\begin{tabular}{|llll|}
\hline \multirow{3}{*}{ Perception } & Satisfactory level & \multicolumn{1}{|c|}{$\begin{array}{l}\text { No. of } \\
\text { cases } \\
(\mathbf{n = 9 6 1 )}\end{array}$} & $\%$ \\
\hline \multirow{3}{*}{ Pain } & Mild pain (1-3) & 478 & 49.7 \\
\cline { 2 - 4 } & Moderate pain (4-6) & 416 & 43.2 \\
\cline { 2 - 4 } Anxiety & Severe pain (7-10) & 67 & 6.9 \\
\hline \multirow{3}{*}{} & No anxiety (0-3) & 342 & 35.6 \\
\cline { 2 - 4 } & Little anxiety (4-5) & 408 & 42.5 \\
\cline { 2 - 4 } & $\begin{array}{l}\text { Somewhat anxious } \\
(6-7)\end{array}$ & 137 & 14.3 \\
\cline { 2 - 4 } & Very anxious (8-10) & 74 & 7.7 \\
\hline
\end{tabular}

Table 5: Symptoms at follow up.

\begin{tabular}{|lll|}
\hline Symptoms & $\begin{array}{l}\text { No. of cases } \\
(\mathbf{n = 4 9 2})\end{array}$ & $\%$ \\
\hline Pain & 82 & 16.70 \\
\hline Hanging Tail & 28 & 5.70 \\
\hline Heavy Bleeding & 12 & 2.40 \\
\hline Foul Smelling Discharge & 6 & 1.20 \\
\hline No Symptoms & 364 & 74 \\
\hline
\end{tabular}

As shown in Table 5, pain (16.7\%) and hanging tails $(5.7 \%)$ were the most common symptoms reported, while heavy bleeding was the most important reason for IUCD removal. Out of 12 cases who complained of heavy 
bleeding at follow up, 10 patients opted for removal $(83.3 \%)$.

Table 6: Distribution of cases according to examination findings.

\begin{tabular}{|lll|}
\hline Examination Findings & $\begin{array}{l}\text { No. of cases } \\
(\mathrm{n}=492)\end{array}$ & $\%$ \\
\hline Expulsion Partial or Complete & 31 & 6.30 \\
\hline Loacl Infection & 33 & 6.70 \\
\hline Missing Strings & 62 & 12.60 \\
\hline $\begin{array}{l}\text { Menstrual Problem or } \\
\text { Bleeding }\end{array}$ & 41 & 8.30 \\
\hline None & 325 & 66.10 \\
\hline
\end{tabular}

As shown in Table 6, On follow up examination, there was missing strings in $12.6 \%$ cases, local infection in $6.7 \%$ cases, partial /complete expulsion in $6.3 \%$ cases, bleeding per vaginum in $8.3 \%$ cases while in $66.1 \%$ of cases there were no abnormal findings.

On further investigating the 62 cases with missing string with help of uterine-sound and ultrasonography, we found that 24 cases had IUCD in situ, in 38 cases IUCD was expelled out but none of the cases reported displaced IUCD.

Table 7: Follow up study for reason of desire for removal of IUCD.

\begin{tabular}{|lll|}
\hline Reason & $\begin{array}{l}\text { No. of cases } \\
(\mathbf{n}=62)\end{array}$ & $\%$ \\
\hline Lack of satisfaction & 43 & 69.40 \\
\hline Want to use other methods & 8 & 12.90 \\
\hline Wants Pregnancy & 5 & 8.10 \\
\hline Other & 6 & 9.70 \\
\hline
\end{tabular}

As depicted in Table 7, lack of satisfaction was the prime reason amongst the 62 cases who desired removal of IUCD.

At follow up $91.3 \%$ clients replied favorably about their satisfaction for PPIUCD.

Table 8: Continuation rate in the study after first follow up (6 weeks).

\begin{tabular}{|lll|}
\hline Total insertions & 961 & $\%$ \\
\hline Total followed-up & 492 & \\
\hline Expulsion & 48 & 9.75 \\
\hline Removal & 62 & 12.6 \\
\hline Continuation & 382 & 77.7 \\
\hline
\end{tabular}

As shown in Table 8, total no. of IUCD insertion in the study was 961, of which 492 cases reported for follow up. Among the cases followed up, $9.75 \%$ had spontaneous expulsion of IUCD and $12.6 \%$ cases sought voluntary removal, while $77.7 \%$ of the cases continued using IUCD as an acceptable method of contraception at follow up.

\section{DISCUSSION}

In the present study undertaken on 1800 cases who were counseled for PPIUCD insertion, acceptance rate was $53.3 \%$ (961 cases) which is higher than the study conducted in Assam by Doley R et al (36.6\%), study done by Mishra S et al (17.17\%) while Goswamy $\mathrm{G}$ et al found $66.6 \%$ acceptance. ${ }^{6-8}$ The variation in acceptance rate may be due to different study settings, locality and diversity in socio-demographic characteristics.

In this study, majority ( $85.1 \%$ ) of the PPIUCD acceptors belonged to younger population (age group of 21- $30 \mathrm{yrs}$ ) which is comparable with other studies done by Doley $\mathrm{R}$ et al, and Katheki $G$ et al whereas in a study by Maluchuru $S$ et al from Guntur, the highest rate of acceptance was among age group of 30-39 years $(27.67 \%) .6,9,1093 \%$ of the acceptors were Hindu, $49.8 \%$ of the acceptors belonged to lower socioeconomic group and $62.6 \%$ from rural localities. $49.5 \%$ clients and $55.4 \%$ of the partners were educated up to high school.78.1\% were homemaker and $61.7 \%$ of the partners were laborer. Similarly, by Maluchuru $\mathrm{S}$ et al, found acceptance was high among low socioeconomic women $(67 \%) .{ }^{10}$ In a study done in Belgaum by Rati SA et al comparable results were found. ${ }^{11}$ With context to the type of family, $83.7 \%$ of women were from joint family. Majority $(89.9 \%)$ of women were housewife, $57.3 \%$ of husbands were semiskilled workers. Most of the families (62\%) had income less than Rs. 3000 per month. Similar findings were reported by Deshpande $S$ et al while in a similar study done in Telangana by Jairaj $\mathrm{S}$ et al majority were from urban area $(79.75 \%)$ and those who completed their secondary school level education $(23.3 \%) .{ }^{12,13}$

In current study most of the clients $(58.9 \%)$ were unbooked ( $<3$ Antenatal visits) and $66.1 \%$ were primipara. In study done by Jairaj $\mathrm{S}$ et al and Gautam et al acceptance rate was higher in primiparous women. ${ }^{13,14}$ In contrast, in the study by Sudha CP et al $98.3 \%$ patients who had PPIUCD inserted were booked and only $1.7 \%$ patient were unbooked and acceptance rate was comparable between primigravidae (36.7\%) and multigravidae $(38.3 \%)$ women. Deshpande $\mathrm{S}$ et al found a higher acceptance rate among multiparas. ${ }^{15,12}$ These findings suggests that the mothers with a recent first experience of delivery were more receptive to PPIUCD as a semi-permanent method of contraception.

Out of 961 IUCD insertion done in the study, 647 $(67.3 \%)$ were post placental, 306 (31.8\%) were intracesarean and $8(0.8 \%)$ were post partum insertion. In the study done by Doley $\mathrm{R}$ et al intracesarean insertion were $77.07 \%$ and post placental in $22.93 \%$. Vidyaramana et al reported similar findings. ${ }^{6,16,17}$

In the study done by Kumar $\mathrm{S}$ et al about half of the IUCDs were post-placental insertions and nearly onethird were inserted during $\mathrm{C}$-section which is comparable. 
In the current study among the acceptors most of the cases i.e. $53.1 \%$ were counseled for PPIUCD insertion during their antenatal period irrespective of the number of visits per patient. $36.3 \%$ cases were counseled during early labor, $9.8 \%$ after the delivery and $0.8 \%$ cases were counseled during postpartum period which is similar to studies by Zeroi et al, Saliman et al and Duong et al which emphasize the need of counseling in antenatal period. ${ }^{18,19,20}$

In present study maximum number of PPIUCD insertion were done by instrument (89\%). In study conducted by Nidhi Gupta et al it was found that there was no statistically significant difference in the discomfort during insertion or in removal rates by either of techniques which is in line with present study. ${ }^{21}$

Present study shows that maximum number of cases $(42.5 \%)$ had little anxiety and $7.7 \%$ were very anxious at the time of PPIUCD insertion. $49.7 \%$ experienced mild pain and $6.9 \%$ of the case perceived severe pain at the time of IUCD insertion. Most of the clients were later convinced after their fears and doubts were addressed prior to discharge. In a study by Sudha $\mathrm{CP}$ et al it was reported that $8.3 \%$ of the patients were anxious, $86.7 \%$ of the patients who had vaginal insertion experienced mild pain at the time of insertion (mean pain score- 2.20). ${ }^{15}$ Somesh Kumar et al in their study also found only a small proportion of women (1-2\%) reported that the insertion was painful or very painful during or after insertion. ${ }^{17}$

At follow up majority i.e. 364 (74\%) clients had no complain and reported for a regular check up, $16.7 \%$ had complain of pain, $5.7 \%$ had hanging tail causing discomfort. On per speculum examination we cut short the string of IUCD if it was unusually long and causing discomfort. $2.4 \%$ of the followed up cases had complain of heavy bleeding and $1.2 \%$ of cases had foul smelling discharge.

On examination 31 cases $(6.3 \%)$ had expulsion of IUCD of which 21 cases had partial expulsion and $6.7 \%$ cases had local infection, $12.6 \%$ had missing CuT string, $8.3 \%$ cases had bleeding per vaginum while $66.1 \%$ cases had no abnormal finding on examination. According to PPIUCD reference manual spontaneous expulsion occurs in about $2-8 \%$ clients and is mostly during first 3 months of insertion and during menstrual periods. ${ }^{1}$

Present study shows that during follow up examination in 62 cases (i.e. $12.6 \%$ ) string were not visualized on per speculum examination (missing string). As per management protocol for missing string, we further investigated these cases with uterine sound and ultrasound examination and found that of these, 24 cases $(38.7 \%)$ had IUCD in proper position while none of the IUCD was found to be displaced. In 38 cases $(61.3 \%)$ IUCD had expelled spontaneously. Study done by O' Hanley et al showed the expulsion rate of about $7-15 \%$ at six month. ${ }^{22}$ Another study done by Eroglu et al showed the expulsion rates in immediate and early post-partum insertion groups are higher than in the interval group. ${ }^{23}$ In the study conducted by Deshpande S et al $62.17 \%$ women had an uneventful course of after PPIUCD, menstrual disturbances in $27 \%$, abdominal pain in $9.29 \%$, and infection in $2 \%$ women. ${ }^{12}$ In the study done by Doley $\mathrm{R}$ et al out of 1217 patients (Total accepted), 939 turned for follow up, of these 314 had complications/complaints. ${ }^{6}$ It was observed that $12.35 \%$ had irregular bleeding, $15.12 \%$ had missed thread, $3.09 \%$ and $0.75 \%$ had expulsion and infection respectively and $2.13 \%$ had pain abdomen which is comparable to our study.

In the present study reason for removal of IUCD was evaluated. Total 62 cases desired for IUCD removal at their follow up visit, commonly (69.4\%) due to complications. $12.9 \%$ wanted to use other method of contraception, $8.1 \%$ cases wanted pregnancy and in $9.7 \%$ cases other causes like family pressure, non-acceptance by partner, religious beliefs etc were there.

In this study $51.19 \%$ cases followed up, $48.9 \%$ cases were lost to follow up after discharge which is comparable with study done by Doley $\mathrm{R}$ al. ${ }^{6}$ In our study rate of spontaneous expulsion is $9.75 \%$ and voluntary removal in $12.6 \%$ i.e. $77.7 \%$ was the continuation rate after first follow up (6 weeks). Mishra $\mathrm{S}$ et al, found expulsion rate $6.4 \%$ at 6 weeks. ${ }^{7} 23.05 \%$ participants were lost follow up. Gunjan Goswamy et al found expulsion rate was $10 \%$ and $30 \%$ lost follow up. ${ }^{8}$ In their study bleeding/discharge (30\%), abdominal pain $(20 \%)$, family pressure $(20 \%)$, just did not want to continue $(5 \%)$ were the reasons they found for removal of IUCD in the follow up. Maluchuru S et al found bleeding (27.27\%), menstrual disturbances $(18.18 \%)$, pressure from family $(27.27 \%)$ pain $(9 \%)$ and other problem $(18.18 \%)$ as reasons for removal. ${ }^{10}$ Majority of the studies including current study observed pain and bleeding as the main problems for removal of IUCD.

Although pain was the commonest complaint at follow up but excessive bleeding was the leading cause where clients sought removal of IUCD $(83.3 \%)$ These finding is quite similar to the finding by ESHRE copri workshop Group in Milan in which bleeding and pain are the most common reasons for removal rate of $10 \%$ in the first year and up to $50 \%$ within 5 years. ${ }^{24}$ Doley $\mathrm{R}$ et al reported that in $42.11 \%$ recipients, PPIUCD were removed due to bleeding followed by pressure from family (17.54\%) The continuation rate was $90.84 \%$ and failure rate was $0.11 \% .^{6}$

The proportion of cases seeking medical attention for problems was $26.2 \%$ of which $46.5 \%$ opted for removal of IUCD. Out of the 492 cases followed up $91.3 \%$ cases were found to be satisfied with the decision of using PPIUCD. This is in line with the study conducted by Kumar S et al where nearly all women were satisfied at the time of insertion and over $90 \%$ reported that they 
were happy with the IUCD at six weeks following insertion. ${ }^{17}$

\section{CONCLUSION}

To conclude, we found average acceptance rate, good continuation rate and no major complication with PPIUCD. Inserting IUCD within 10 minutes after placental delivery and during cesarean section is a one time, long term, coitus independent, reversible, demonstrably safe and effective method of contraception having low expulsion rate and has no effect on breast feeding.

The government needs to develop strategies to increase public awareness for PPIUCD as a safe and effective contraceptive method along with continuous training and enhancement of the knowledge and skills of the health care providers. Incentives to the acceptors, motivators and of course providers will play a key role in expanding the scope of PPIUCD in the near future.

\section{ACKNOWLEDGMENTS}

Authors would like to thank clients and colleagues for their cooperation.

\section{Funding: No funding sources}

Conflict of interest: None declared

Ethical approval: The study was approved by the Institutional Ethics Committee

\section{REFERENCES}

1. IUCD Reference Manual for MOs and Nursing Personnel; 2013. Available from http://www.nrhmtn.gov.in/modules/IUCD_Reference _Manual_for_MOs_and_Nursing_Personne_-FinalSept_2013.pdf

2. Trends in Maternal Mortality: 1990 to 2015 Estimates by WHO, UNICEF, UNFPA, World Bank Group and the United Nations Population Division. Retrieved from http://www.afro.who.int/sites/default/files/201705/trends-in-maternal-mortality-1990-to-2015.pdf

3. Cleland J. Family planning: The unfinished agenda. The Lancet. 2006;368(9549):1810-27.

4. Family planning in India. In Wikipedia, The Free Encyclopedia. Retrieved. 12;50:2017. Available at https://en.wikipedia.org/w/index.php?title=Family_pl anning_in_India\&oldid=815889048.

5. Medical eligibility criteria for contraceptive use, Fifth edition 2015. Available at http://apps.who.int/iris/bitstream/10665/181468/1/97 89241549158_eng.pdf

6. Doley R, Pegu B. A retrospective study on acceptability and complications of PPIUCD insertion. J Evolution Med. Dent. Sci. 2016;5(31):1631-4
7. Mishra S. Evaluation of safety, efficacy, and expulsion of post-placental and intra-cesarean insertion of intrauterine contraceptive devices (PPIUCD). J Obstet Gynaecol India. 2014;64(5):33743.

8. Goswami G. A Prospective Study to Evaluate Safety, Efficacy and Expulsion Rate of Post Placental Insertion of Intra Uterine Device. J Evol Medic Dental Sci. 2015;4(56):9770-4.

9. Rati MS, Jawadagi MS, Pujari MJ. A Study to Assess the Factors Affecting Acceptance of Intrauterine Device (IUD) Among Rural Women of Hirebagewadi, Belgaum. IOSR J Nurs Health Sci. 2014;3:37-52.

10. Katheit G, Agarwal J. Evaluation of post placental intrauterine contraceptive device (PPIUCD) in terms of awareness, acceptance and expulsion in a tertiary care centre. Int J Reprod Contracept Obstetr Gynaecol. 2013;2(4):539-43.

11. Maluchuru S, Aruna V, Prabhavathi N. Post partum intrauterine device insertion-2 years experience at tertiary care center in Guntur medical college/govt general hospital, Guntur. JDMS. 2015;14(3):56-61.

12. Deshpande S, Gadappa S, Yelikar K, Wanjare N, Andurkar S. Awareness, acceptability and clinical outcome of post-placental insertion of intrauterine contraceptive device in Marathwada region, India: Indian J Obstetr Gynecol Res. 2017;4(1):77-82.

13. Jairaj S, Dayyala S. A cross sectional study on acceptability and safety of IUCD among postpartum mothers at tertiary care hospital, Telangana. J Clinic Diagnostic Res. JCDR. 2016;10(1):LC01.

14. Gautam R, Arya KN, Kharakwal S, Singh S, Trivedi M. Overview of immediate PPIUCD application in Bundelkhand region. J Evol Med Dent Sci. 2014;3(36):9518-26.

15. Sudha CP, Priyanka HK, Nagaiah D. A study to evaluate safety and efficacy of immediate postpartum postplacental IUCD insertion. Int $\mathbf{J}$ Reprod Contracept Obstet Gynecol. 2017;6:2284-8.

16. Vidyarama R, Nagamani T, Prasad K. Ppiucd as a long acting reversible contraceptive (larc) an experience at a tertiary care centre. Int J Scientific Res. 2015;4(5):5-7.

17. Kumar S, Sethi R, Balasubramaniam S, Charurat E, Lalchandani K, Semba R, et al. Women's experience with postpartum intrauterine contraceptive device use in India. Reprod Health. 2014;11(1):32.

18. Zerai A, Tsui AO. The relationship between prenatal care and subsequent modern contraceptive use in Bolivia, Egypt and Thailand. Afr J Reprod health. 2001;5(2):68-82.

19. Saliman MH. Impact of antenatal counselling on couple knowledge and proctice of contraception in Mansoura, Egypt. East Mediteranean Health J. 1999;5(5):1002-13.

20. Duong DV, Lec AH, Binns, CW. Contraception within six month postpartum in rural Vietnam; Implication on Family Planning and maternity 
services. European J Contracept Reproduct Health Care. 2005;10(2):111-8.

21. Gupta N, Sinha R, Prateek S, Mangal A. A randomized study for two techniques of immediate post-partum intrauterine contraceptive device insertion in India. Int $\mathbf{J}$ Reprod Contracept Obstet Gynecol. 2014;3:398-402.

22. O'Hanley K, Huber DH. Postpartum IUCDs: key for success Association for Voluntary surgical contraception New York, 1992;45(4):351-61.

23. Eroglu K, Akkuzu G, Vural G, Dilbaz B, Akin A, Complications of IUD insertion in immediate postplacental/ Early postpartum period with interval period: 1 year follow up contraception, 2006;74(5):376-81.

24. The ESHRE Capri Workshop Group. Intrauterine devices and intrauterine systems. Hum Reprod update. 2008;14:197-208.

Cite this article as: Chauhan $\mathrm{R}$, Sahni $\mathrm{S}$, Hanumantaiya S. Evaluation of acceptability, safety and expulsion rate of PPIUCD. Int J Reprod Contracept Obstet Gynecol 2018;7:1083-9. 